\title{
Antidepressants Influence Somatostatin Levels and Receptor Pharmacology in Brain
}

\author{
Eleftherios Pallis 1,4,5, Anna Vasilaki ${ }^{1,2,5,6}$, Dominique Fehlmann², Andreas Kastellakis ${ }^{1,3}$, Daniel Hoyer ${ }^{2}$, \\ Christina Spyraki ${ }^{1, *}$ and Kyriaki Thermos*, I
}

'Department of Basic Sciences, Laboratory of Pharmacology, Faculty of Medicine, University of Crete, Heraklion, Crete, Greece; ${ }^{2}$ Neuroscience Research, Novartis Institutes for Biomedical Research, Basel, Switzerland; ${ }^{3}$ Department of Psychology, School of Social Sciences, University of Crete, Crete, Rethymnon, Greece

\begin{abstract}
This study investigated how the administration (acute and chronic) of the antidepressants citalopram and desmethylimipramine (DMI) influences somatostatin (somatotropin release inhibitory factor, SRIF) levels and SRIF receptor density (sst $1-5$ ) in rat brain. Animals received either of the following treatments: (I) saline for 2 I days (control group), (2) saline for 20 days and citalopram or DMI for I day (citalopram or DMI acute groups), (3) citalopram or DMI for 21 days (citalopram or DMI chronic groups). Somatostatin levels were determined by radioimmunoassay. [ ${ }^{125}$ I]LTT SRIF-28 binding in the absence (labeling of sst $_{1-5}$ ) or presence of $3 \mathrm{nM}$ MK678 (labeling of $\mathrm{sst}_{1 / 4}$ ) and $\left[{ }^{125} \mathrm{l}\right] \mathrm{Tyr}^{3}$ octreotide (labeling of $\mathrm{sst}_{2 / 5}$ ) binding with subsequent autoradiography was performed in brains of rats treated with both antidepressants. Somatostatin levels were increased after citalopram, but not DMI administration, in the caudate-putamen, hippocampus, nucleus accumbens, and prefrontal cortex. Autoradiography studies illustrated a significant decrease in receptor density in the superficial and deep layers of frontal cortex (sst ${ }_{2}$ ), as well as a significant increase in the CAI (sst//4) hippocampal field in brains of

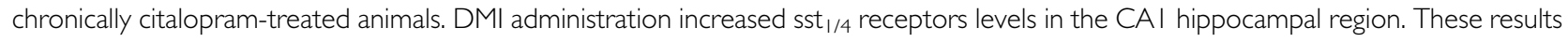
suggest that citalopram and to a lesser extent DMI influence the function of the somatostatin system in brain regions involved in the emotional, motivational, and cognitive aspects of behavior.

Neuropsychopharmacology (2009) 34, 952-963; doi: I0.1038/npp.2008.133; published online 17 September 2008
\end{abstract}

Keywords: somatostatin; citalopram; desmethylimipramine; receptor binding; autoradiography; neuropeptide

\section{INTRODUCTION}

A significant number of studies conducted in the past several years have provided considerable information on the neurobiology of mood disorders. Although these investigations have advanced the field considerably, more studies are essential to aid our understanding of the pathophysiology of depression. Tricyclic antidepressants, developed several decades ago triggered the formulation of the monoamine hypothesis that now appears insufficient to explain the biology of depression. Although drugs that increase the availability of neurotransmitters in the brain

\footnotetext{
*Correspondence: Professor K Thermos, Department of Basic Sciences, Laboratory of Pharmacology, Faculty of Medicine, University of Crete, Heraklion, Crete 7I I 10, Greece, Tel: + 302810 394533, Fax: + 302810 394530, E-mail: thermos@med.uoc.gr

${ }^{4}$ Current address: Laboratory of Pharmacology, School of Medicine, University of Athens, Athens, Greece.

${ }^{5}$ These authors contributed equally to this work.

${ }^{6}$ Current address: Laboratory of Pharmacology, School of Medicine, University of Thessaly, Larissa, Greece.

We announce with great sorrow that our colleague and friend Professor Christina Spyraki passed away on 2 September 2006.

Received 20 March 2008; revised 17 July 2008; accepted 17 July 2008
}

represent the primary medical treatment of depression, such approaches remain inadequate therapies in terms of safety, efficacy, and onset of effect. The search for new molecules and targets, which may be complementary rather than competing therapies for the symptomatology of depression, represents a challenge on both scientific and therapeutic fronts (Skolnick et al, 2001). A wide array of antidepressant drugs with different mechanisms of action have been developed (Berton and Nestler, 2006; Wong and Licinio, 2004). Recently, the focus turned onto neuropeptide systems such as substance $\mathrm{P}$ and CRH (Bissette et al, 2003; Zobel et al, 2000; Kramer et al, 1998), as new therapeutic targets. We have focused our research interest over the past several years on the study of the involvement of somatostatin in the mechanism of antidepressant drugs and the biology of depression.

Somatotropin release inhibitory factor (SRIF) is synthesized in nuclei of the basal ganglia, eg caudate-putamen $(\mathrm{CPu})$ and nucleus accumbens $(\mathrm{NAc})$, implicated in motor and affective disorders (Brownstein et al, 1975; Vincent and Johansson, 1983), although cortical and subcortical SRIF has been implicated in the pathophysiology of psychiatric disorders (Rubinow, 1986). SRIF mediates a variety of physiological and behavioral actions by interacting with five 
somatostatin receptor subtypes ( $\mathrm{sst}_{1-5}$; Hoyer et al, 1995). In the NAc, the sst $_{1}$ receptor has been reported to be an autoreceptor for SRIF (Vasilaki et al, 2004; Thermos et al, 2006), whereas the $s_{2} t_{2}$ receptor appears to be responsible for the actions of SRIF on dopamine release and dopaminemediated behaviors (Raynor et al, 1993; Thermos et al, 1996; Hathway et al, 1999).

A limited number of studies have linked depression or the effect of antidepressants with the activity of the SRIF system. Cerebrospinal fluid (CSF) SRIF-like immunoreactivity (SRIF-LI) levels have been shown consistently to be reduced in patients with major depression and to be normalized during recovery (Bissette et al, 1986; Rubinow, 1986; Pazzaglia et al, 1995). Interestingly, Gerner and Yamada (1982) reported significant reductions in SRIF levels in the CSF of depressed patients, whereas increased levels were observed in patients with mania, a finding that was not observed by others (Rubinow et al, 1983). However, a lack of alterations in SRIF-LI in post-mortem cortical tissue of depressed patients was also reported (Charlton et al, 1988).

Animal studies have also implicated SRIF in the pathophysiology of depression. Kakigi et al (1992) reported reduced SRIF content in brain regions following a 10-day treatment with the specific serotonin uptake inhibitors clomipramine and zimelidine, but not with imipramine. Similarly, acute and chronic treatments with citalopram, a widely used selective serotonin reuptake inhibitor (SSRI), led to reduced SRIF levels and mRNA in the striatum (Prosperini et al, 1997). A gradual increase of the expression of SRIF was observed in the rat dentate gyrus and piriform cortex following multiple electroconvulsive stimulation, which mimics antidepressant treatment (Mikkelsen and Woldbye, 2006).

We have reported structural (Gheorvassaki et al, 1992) and functional (Pallis et al, 2001) evidence for selective increased SRIFergic activity in the NAc, following chronic desmethylimipramine (DMI) treatment. More recently, we have shown that both chronic citalopram and DMI treatments increased the extracellular levels of SRIF in the NAc, in vivo, with citalopram having a larger effect on the SRIF system (Pallis et al, 2006).

It is apparent from the above-mentioned experimental studies that antidepressants that selectively target the serotoninergic system have a more profound effect on the alterations produced at the SRIF system. To pursue this further, the present investigation focused on the effects of acute and chronic administration of two antidepressants, namely DMI (a tricyclic antidepressant) and citalopram (an SSRI) on SRIF levels and SRIF receptor regulation in different brain regions of the rat.

\section{MATERIALS AND METHODS}

\section{Animals}

Male Sprague-Dawley rats (270-330 g; Charles Rivers, Italy) were used in all experiments. Rats were group-housed (2-3 per cage) in a temperature-controlled room $\left(21 \pm 1^{\circ} \mathrm{C}\right)$ with a $12 \mathrm{~h}$ light-dark cycle. Food and water were provided ad libitum. All procedures were performed in accordance with the guidelines for care and use of experimental animals (EEC Council 86/609; 27/01/1992, No 116).

\section{Antidepressant Treatment}

The chronic antidepressant-treated groups received for 21 days, citalopram $(20 \mathrm{mg} / 2 \mathrm{ml} / \mathrm{kg}$; i.p., once daily) or DMI ( $5 \mathrm{mg} / 2 \mathrm{ml} / \mathrm{kg}$; i.p., twice daily), respectively. The acute antidepressant-treated groups received saline $(2 \mathrm{ml} / \mathrm{kg}$, i.p., once or twice daily) for 20 days and for 1 day citalopram (20 mg/2 ml/kg, i.p., once daily) or for 1 day DMI ( $5 \mathrm{mg} /$ $2 \mathrm{ml} / \mathrm{kg}$, i.p., twice daily). Finally, the citalopram and DMI control groups received saline for 21 days $2 \mathrm{ml} / \mathrm{kg}$, i.p., once or twice daily, respectively. All animals were killed $24 \mathrm{~h}$ after the last injection.

DMI-HCl was obtained from RBI, Natick, MA, USA and citalopram- $\mathrm{HBr}$ was kindly provided from $\mathrm{H}$ Lundbeck A/S, Copenhagen, Denmark. Both drugs were dissolved in saline just before use.

\section{Tissue Preparation for Measurement of SRIF Levels}

Prefrontal cortex (PFCx), $\mathrm{CPu}, \mathrm{Nac}$, and hippocampus were dissected from $1 \mathrm{~mm}$ thick sections according to Palkovits and Brownstein (1988). Samples (3 mg of wet tissue per $\mathrm{ml}$ ) were boiled for $10 \mathrm{~min}$ in $2 \mathrm{~N}$ acetic acid, sonicated for $2 \mathrm{~min}$ and kept at $-80^{\circ} \mathrm{C}$ for $24-48 \mathrm{~h}$. Subsequently, samples were centrifuged (12000 r.p.m., $20 \mathrm{~min}, 4^{\circ} \mathrm{C}$ ) and the supernatants were removed, lyophilized and stored at $-80^{\circ} \mathrm{C}$ until they were analyzed for SRIF levels using radioimmunoassay (RIA).

\section{Radioimmunoassay}

The samples were diluted in RIA buffer containing, $0.10 \mathrm{M}$ sodium phosphate $(\mathrm{pH} 7.4), 0.1 \%$ Triton $\mathrm{X}-100,0.5 \%$ bovine serum albumin (BSA), and $0.1 \%$ sodium azide. For the determination of SRIF levels, a rabbit antiserum raised against SRIF (Barbar) was used at a final concentration of 1:9000 (kindly provided by Dr J Epelbaum). Synthetic SRIF (Tocris; Cookson Inc., USA) at a range of $0.78-100 \mathrm{pg}$ and $\left[{ }^{125} \mathrm{I}\right] \mathrm{Tyr}^{11}$-SRIF (20 000 c.p.m.; $2000 \mathrm{Ci} / \mathrm{mmol}$; Amersham, Vienna, Austria) were used as standard and radiolabeled tracer, respectively. Synthetic SRIF $54.95 \pm 7.35 \mathrm{pg}$ displaced $50 \%$ of the radioactive tracer. The mixture was incubated at $4{ }^{\circ} \mathrm{C}$ for $24 \mathrm{~h}$. Bound and free SRIF were separated by addition of $1 \mathrm{ml}$ ethanol and subsequent centrifugation at 4000 r.p.m., $4^{\circ} \mathrm{C}$ for $20 \mathrm{~min}$. The precipitates of the centrifugation were counted in a gamma counter (LKBWallac, Turku, Finland; 75\% efficiency).

Total tissue protein concentration was calculated according to Bradford (1976). Data were expressed in pg of SRIF per $\mu \mathrm{g}$ of total tissue protein. All samples were found to be within the range of the assay $(0.78-100 \mathrm{pg} / \mu \mathrm{g}$ of total protein). SRIF tissue levels for each brain area studied were analyzed using two-tailed $t$-test analysis and one-way analysis of variance (ANOVA) followed by the post-test for linear trend to test whether there is a trend such that the values increase or decrease as the exposure to the antidepressants is increased. The statistical software GraphPad Prism version 4.00 for Windows (GraphPad 
Software, San Diego, CA, USA) was used for the statistical analysis. $p<0.05$ was considered statistically significant.

\section{Receptor Autoradiography Studies}

Receptor autoradiography studies were performed in all animal groups (three animals per group). Brains were cut at $10 \mu \mathrm{m}$ sections. Receptor autoradiography was performed according to the following procedure (Fehlmann et al, 2000): after $20 \mathrm{~min}$ of preincubation in buffer containing $50 \mathrm{mM}$ Tris- $\mathrm{HCl}, 2 \mathrm{mM}$ EGTA, $5 \mathrm{mM} \mathrm{MgCl}_{2}, 0.1 \mathrm{mM}$ bacitracin, and $0.2 \%$ BSA (pH 7.4), at room temperature (RT), the sections were incubated for $2 \mathrm{~h}$ at $\mathrm{RT}$ in the same medium supplemented with $50 \mathrm{pM}\left[{ }^{125}\right.$ I]LTT SRIF-28 in the absence (to label all SRIF receptors) or the presence of $3 \mathrm{nM}$ MK678 (to label sst ${ }_{1}$ and $\mathrm{sst}_{4}$ receptors) or $50 \mathrm{pM}\left[{ }^{125} \mathrm{I}\right] \mathrm{Tyr}^{3}$ octreotide (to label $\mathrm{sst}_{2}$ and $\mathrm{sst}_{5}$ receptors). Nonspecific binding was determined in a set of adjacent slides by incubation in the presence of $1 \mu \mathrm{M}$ SRIF-28 (Tocris; Cookson Inc.). The washing of labeled sections was carried out as follows: brief dipping into ice-cold $\mathrm{ddH}_{2} \mathrm{O}$ followed by two $10 \mathrm{~min}$ washes in the former buffer (without radioligand) and a brief dipping in ice-cold $\mathrm{ddH}_{2} \mathrm{O}$ to remove salts. Finally, the sections were dried under a stream of cold air. The aforementioned radioligands (Siehler et al, 1999) were custom synthesized to a specific activity of $2175 \mathrm{Ci} / \mathrm{mmol}$ by ANAWA (Wangen, Switzerland).

Autoradiograms were generated by apposing the labeled tissues to BioMax Films (Kodak) at $4^{\circ} \mathrm{C}$ for 1 day. Brain area coordinates were taken according to Paxinos and Watson (1998). Photomicrographs of BioMax Film were generated and analyzed using the computerized image analysis system MCID (Imaging Research, ON, Canada). The background OD value of the films was set through the program to 0.035 . During data acquisition, background values were also taken from each individual picture to ensure that our results were not influenced by the background differences in the various film areas. In our experiments, the average background OD values for the three radioligands were: $\left[{ }^{125}\right.$ I]LLT SRIF-28, $0.033 \pm 0.005(n=181$ pictures $) ;\left[{ }^{125}\right.$ I]LLT SRIF- $28+3 \mathrm{nM}$ MK678, $0.035 \pm 0.006 \quad(n=192) ; \quad\left[{ }^{125} \mathrm{I}\right] \mathrm{Tyr}^{11}$ octreotide, $0.035 \pm 0.005(n=180)$; Mean \pm SD.

To convert the $\mathrm{OD}$ values to $\mathrm{nCi} / \mathrm{mg}$ of tissue, $\left[{ }^{125} \mathrm{I}\right]-$ microscales $(0.046-23.7 \mathrm{kBq} / \mathrm{mg}, 1.25-640 \mathrm{nCi} / \mathrm{mg}$; Amersham) were used. Specific binding was calculated as $\mathrm{nCi} / \mathrm{mg}$ assessed in total minus nonspecific binding sections. Data were expressed as means \pm SEM and the statistical comparison between groups was performed using, for each of the radioligands: (1) two-way ANOVA to locate the source of variance (brain area and/or drug treatment) between the animal groups, (2) one-way ANOVA followed by the Dunnett's multiple comparison post-test for each brain area to compare acutely and chronically treated animals to control animals, and (3) one-way ANOVA followed by the post-test for linear trend for each brain area to test whether there is a trend such that the values increase or decrease as the exposure to the antidepressants is increased. Furthermore, a two-way ANOVA for randomized-block data followed by the Bonferroni post-test was performed to locate the source of variation (radioligand and/or treatment) in each brain area. For the statistical analysis of the data, the GraphPad Prism version 4.00 for Windows
(GraphPad Software) was used and $p$-values $<0.05$ were considered statistically significant.

\section{RESULTS}

Acute and chronic administration of citalopram resulted in statistically significant increases of SRIF levels in different brain areas (Figure 1a). The levels of SRIF in the control animals in the four areas examined were PFCx, $0.76 \pm 0.11$; NAc, $1.43 \pm 0.20 ; \mathrm{CPu}, \quad 0.57 \pm 0.06 ;$ and hippocampus $0.51 \pm 0.06 \mathrm{pg} / \mu \mathrm{g}$ of protein. A two-tailed $t$-test analysis indicated an increase of $152.4 \pm 14.3 \%(p<0.05)$ in the PFCx, $167.4 \pm 22.8 \%(p<0.05)$ in the Nac, and $160.3 \pm 25.0 \%$ $(p<0.05)$ in the $\mathrm{CPu}$ of the acutely citalopram-treated animals compared to the control group. Statistically significant increases of SRIF tissue levels were also observed after chronic citalopram treatment in the $\mathrm{PFCx}$ $(198.7 \pm 21.7 \%, p<0.01)$, NAc $(149.1 \pm 17.3 \%, p<0.05)$,
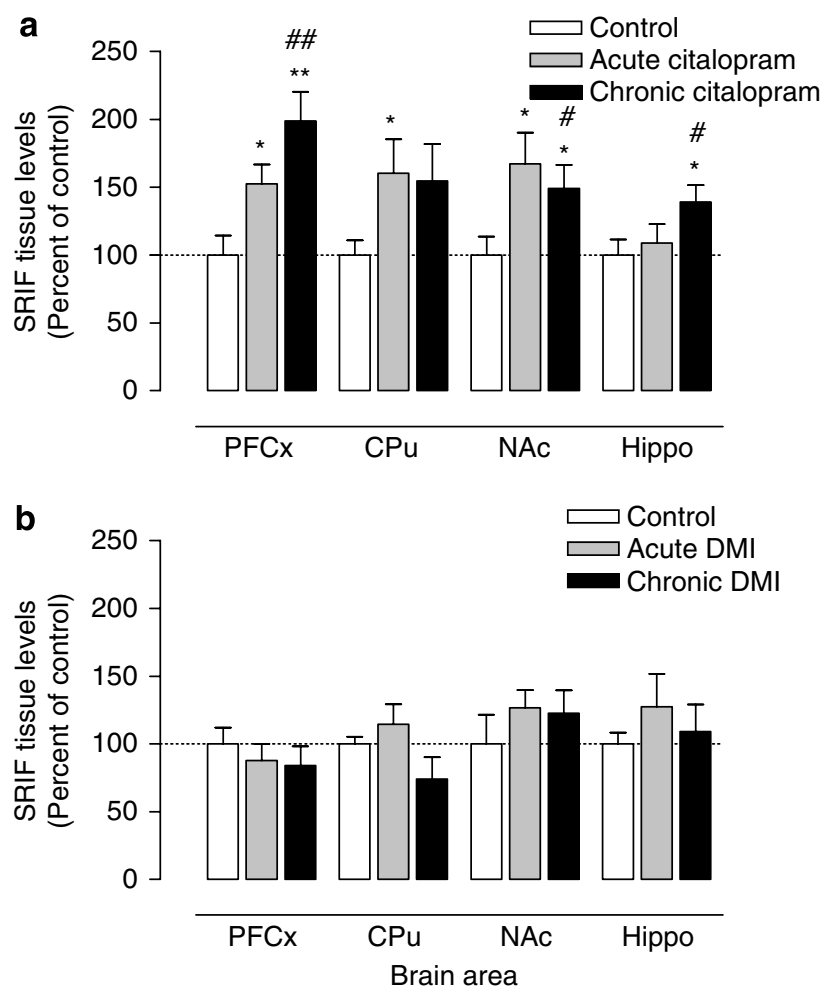

Figure I Effect of acute and chronic antidepressant treatment on somatotropin release inhibitory factor (SRIF) tissue levels in rat brain. (a) Percent changes of SRIF tissue levels after acute and chronic citalopram treatment for each brain area. Basal tissue levels (Mean \pm SEM, pg/ $\mu \mathrm{g}$ of protein) for the brain areas studied were: PFCx $0.76 \pm 0.11$, NAc $1.43 \pm 0.20, \mathrm{CPu} 0.57 \pm 0.06$, Hip 0.5 I $\pm 0.06, n=7-10$ animals per group. The asterisk '*' corresponds to statistically significant SRIF level changes in the different brain areas after citalopram treatment compared with control animals, and sharp '\#' indicates statistically significant differences between groups using one-way analysis of variance (ANOVA) followed by the linear trend post-test. The number of symbols' repetition represents: I, $p<0.05$; $2, p<0.01 ; 3, p<0.001$. (b) Percent changes of SRIF tissue levels after acute and chronic desmethylimipramine (DMI) treatment for each brain area. Basal tissue levels (Mean \pm SEM, pg/ $\mu$ g of protein) for the brain areas

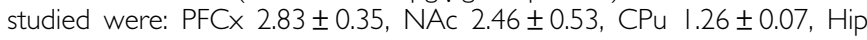
$1.26 \pm 0.11, n=5-10$ animals per group. PFCx: prefrontal cortex, CPu: caudate putamen, NAc: nucleus accumbens, Hip: hippocampus. 
and hippocampus $(139.0 \pm 12.5 \%, p<0.05)$. Analysis of the data with one-way ANOVA followed by the post-test for linear trend depicted a statistically significant trend of the SRIF tissue levels to increase not only in the PFCx $(p<0.01)$ but also in the NAc $(p<0.05)$ and hippocampus $(p<0.05)$, as exposure to citalopram was increased.

Acute and chronic administration of DMI did not result in statistically significant changes of SRIF levels in the four brain areas studied (Figure 1b). The levels of SRIF in the control animals in the four areas examined were as follows: $\mathrm{PFCx} 2.83 \pm 0.35$, NAc $2.46 \pm 0.53, \mathrm{CPu} 1.26 \pm 0.07$, and hippocampus $1.26 \pm 0.11 \mathrm{pg} / \mu \mathrm{g}$ of protein.

To perform an in-depth analysis of the possible changes of the SRIF receptors after antidepressant treatment, radioligand binding studies with subsequent autoradiography were performed. A typical example of autoradiograms is depicted in Figure 2. The specific binding for the radioligands in the different brain areas studied was as follows: [ ${ }^{125}$ I]LTT SRIF-28: frontal cortex areas 85-94\%, NAc (core-C) $85 \%$, NAc (shell-Sh) $60 \%$, CPu $85 \%$, olfactory tubercle (Tu) 58\%, hippocampal areas $83-93 \%$; $\left[{ }^{125}\right.$ I]LTT
SRIF-28 + 3 nM MK678: frontal cortex areas 74-85\%, nucleus accumbens core (NAcC) 57\%, NAcSh 30\%, CPu $66 \%$, Tu 43\%, hippocampal areas $68-89 \%$; and $\left.{ }^{125} \mathrm{I}\right] \mathrm{Tyr}^{11}$ octreotide: frontal cortex areas $80-96 \%$, NAcC $85 \%$, NAcSh $61 \%, \mathrm{CPu} 84 \%$, Tu $63 \%$, hippocampal areas $63-89 \%$.

Two-way ANOVA used to locate the source of variation (brain area and/or drug treatment) between animal groups indicated - as expected - that the binding of radioligands is influenced by the brain area studied $(p<0.0001)$ whereas drug treatment had a differential influence on the binding of (1) $\left[{ }^{125}\right.$ I]LTT SRIF-28 (citalopram: $p<0.0001$; DMI: $p<0.0001)$, (2) [ ${ }^{125}$ I]LTT SRIF-28 in the presence of $3 \mathrm{nM}$ MK678 (citalopram: $p<0.0001$; DMI: $p>0.0001$ ), and (3) $\left[{ }^{125} \mathrm{ITyr}^{3}\right.$ octreotide (citalopram: $p<0.0001$; DMI: $p>0.05$ ). Furthermore, a statistically significant interaction $(p<0.001)$ between brain area and citalopram treatment was observed only with $\left[{ }^{125}\right.$ I]LTT SRIF-28 binding.

One-way ANOVA followed by the Dunnett's multiple comparison post-test designated that after chronic citalopram treatment, the binding of sst $_{1-5}$ selective radioligand ${ }^{[25}$ I]LTT SRIF-28 was decreased in a statistically significant
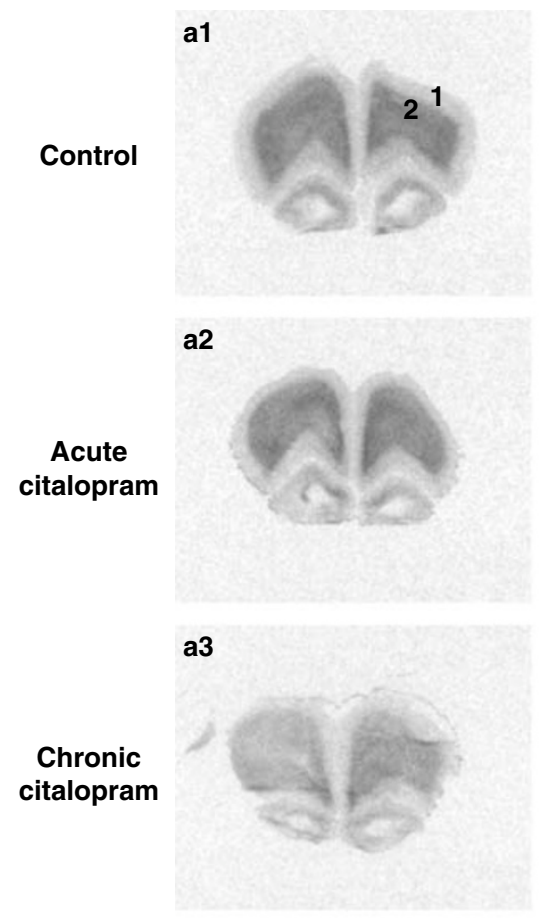

a4

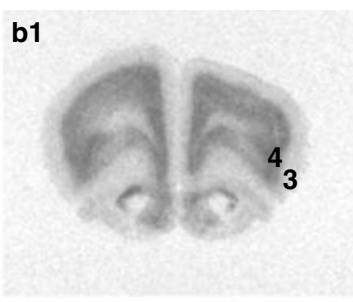

b2

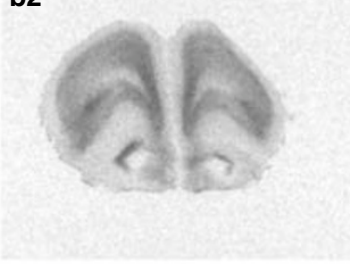

b3

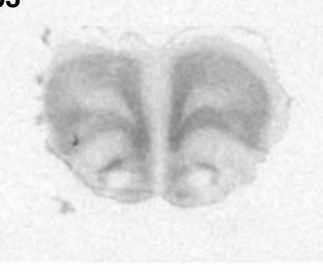

b4 c1

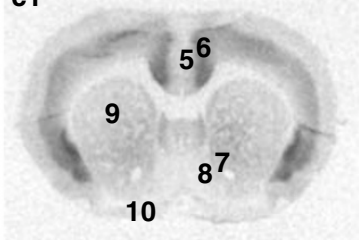

c2

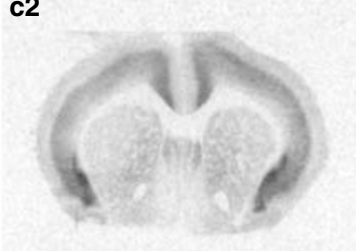

c3

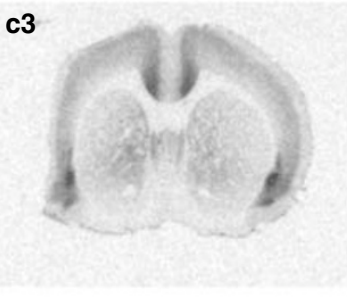

c4

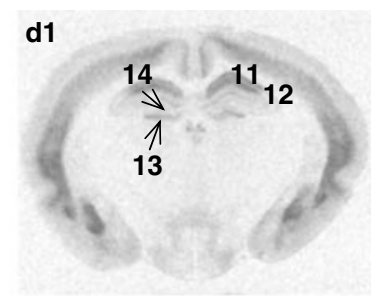

d2

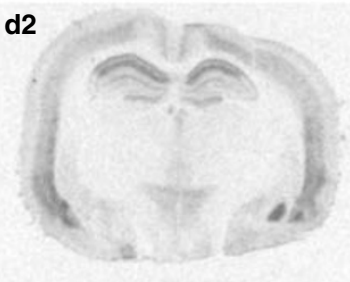

d3

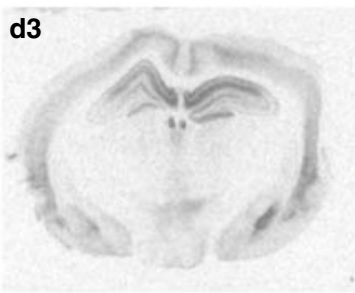

d4

\section{Control}

NS

Figure 2 Representative autoradiograms of [ ${ }^{125}$ I]LTT SRIF-28 binding in rat brain of control (a I-d I), acutely (a2-d2), and chronically (a3-d3) citalopramtreated animals. Sections presented here are from plate 5 (al-a4), plate 8 (b l-b4), plate $\mid 3$ ( $\mathrm{cl}-\mathrm{c} 4)$, and plate $3 \mathrm{l}$ (figures $\mathrm{dl}-\mathrm{d} 4)$ according to Paxinos and Watson (1998). (a4-d4) Corresponding to [ $\left.{ }^{125} \mid\right] \mathrm{LTT}$ SRIF-28 binding on the brain of control animals in the presence of I $\mu M$ SRIF-28 (NS, nonspecific binding). Abbreviations of brain areas: I: FrCxs; superficial layers of frontal association and secondary motor cortex, 2: FrCxd; deep layers of frontal association and secondary motor cortex, 3: Als; superficial layers of agranular insular cortex, 4: Ald; deep layers of agranular insular cortex, 5: CGs; superficial layers of cingulate cortex, 6: CGd; deep layers of cingulate cortex, 7: NAcC; nucleus accumbens core, 8: NAcSh; nucleus accumbens shell, 9: CPu; caudate putamen, I0: Tu; olfactory tubercle, I I: CAI; CAI field of hippocampus, I2: CA2-3; CA2-3 field of hippocampus, I3: DGmol; molecular layer of dentate gyrus, 14: DGgr+ po; granular and polymorph layers of dentate gyrus. 
manner in the deep layers of frontal association and secondary motor cortex (FrCxd (layers IV-VI): $-33.7 \pm 6.9 \%, \quad p<0.01)$ and the superficial (AIs: $-34.9 \pm 6.0 \%, p<0.01$ ) and deep (AId: $-38.4 \pm 5.4 \%$, $p<0.01)$ layers of agranular insular cortex $(\mathrm{AI})$, whereas it increased in the CA1 field of hippocampus $(+17.6 \pm 1.8 \%$, $p<0.05)$ as well as the molecular layer of dentate gyrus (DGmol: $+24.5 \pm 5.8 \%, p<0.05$; Figure 3a; Table 1). No changes were observed after chronic DMI treatment (Table 2). In addition, no changes were observed in the superficial and deep layers of cingulate cortex (CGs and CGd), the core and shell of NAc (NAcC and NAcSh), the $\mathrm{CPu}$, the $\mathrm{Tu}$, the CA2-3 field of hippocampus (CA2-3), and the granular and polymorph layers of dentate gyrus (DGgr + po) of the citalopram or DMI-treated animals (Tables 1 and 2).
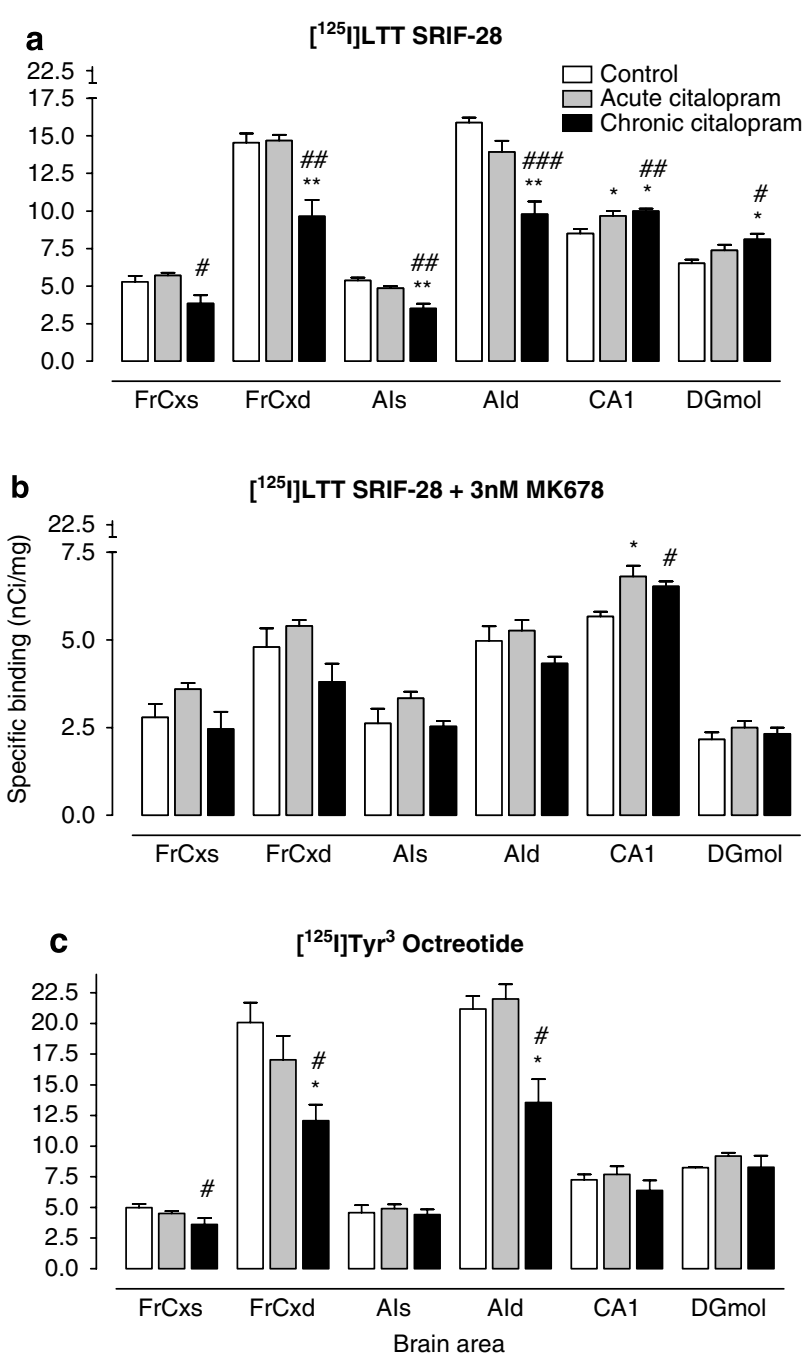

Figure 3 Effect of acute and chronic citalopram administration on $\left[{ }^{125} \mid\right] \mathrm{LTT}$ SRIF-28 (a), $\left[{ }^{125}\right.$ I]LTT SRIF-28 + MK678 (b), and $\left.{ }^{125} \mid\right] T y r^{3}$ octreotide (c) binding in different rat brain regions. Data are means \pm SEM measured in three rats per experimental group and one to five sections for each brain area per animal. $* 00.05$, $* * 0<0.0$ I: statistically significantly different from the animals of control group using one-way analysis of variance (ANOVA) followed by the Dunnett's multiple comparison posttest. ${ }_{p}<0.05, \#_{p}<0.01$ : statistically significant differences between groups using one-way ANOVA followed by the linear trend post-test. For the abbreviations of brain areas see Figure 2.
An increase of $\left[{ }^{125} \mathrm{I}\right] \mathrm{LTT}$ SRIF-28 binding was also observed in the CA1 hippocampal field $(+13.8 \pm 3.9 \%$, $p<0.05$ ) of acutely citalopram-treated animals (Figure 3a; Table 1). No statistically significant changes were observed in any other brain area studied of the acutely citalopramtreated animals and in all brain areas studied of the acutely DMI-treated animal (Tables 1 and 2). However, analysis of the data with one-way ANOVA followed by the post-test for linear trend depicted a statistically significant trend of the binding to decrease in the FrCxs $(p<0.05), \operatorname{FrCxd}(p<0.01)$, AIs $(p<0.01)$, and AId $(p<0.01)$ layers of the cortex and to increase in the CA1 field of hippocampus $(p<0.01)$, and DGmol $(p<0.05)$ layers of dentate gyrus of citalopramtreated animals as the exposure to the antidepressant was increased (Figure 3a; Table 1).

$\left[{ }^{125}\right.$ I]LTT SRIF-28 binding performed in the presence of $3 \mathrm{nM}$ MK678 - thus labeling sst $_{1}$ and sst $_{4}$ receptors - was statistically significantly increased the CA1 field of the hippocampus of acutely citalopram-treated animals (+ $20.1 \pm 5.4 \%, p<0.05$; Figure $3 \mathrm{~b}$; Table 1). No statistically significant changes were detected on $\left[{ }^{125}\right.$ I]LTT SRIF-28 binding in the presence of $3 \mathrm{nM}$ MK678 in sections of chronic citalopram-treated animals but one-way ANOVA followed by the post-test for linear trend depicted a trend $(p<0.05)$ of binding to increase in the CA1 hippocampal field as exposure to citalopram was increased (Table 1).

DMI treatment influenced the binding of $\left[{ }^{125} \mathrm{I}\right] \mathrm{LTT}$ SRIF28 binding to sst $_{1 / 4}$ receptor(s) only in the CA1 hippocampal field after both acute $(+42.0 \pm 4.4 \%, p<0.01)$ and chronic $(+29.5 \pm 1.1 \%, p<0.01)$ administration while an increase of binding was also observed in the FrCxs layers $(+38.0 \pm 6.0 \%, p<0.05)$ of acutely DMI-treated animals (Table 2). Also, analysis of the data with one-way ANOVA followed by the post-test for linear trend depicted a statistically significant trend of the binding to decrease in the AIs $(p<0.05)$ and AId $(p<0.05)$ layers of the cortex of DMI-treated animals as the exposure to the antidepressant was increased (Table 2).

To examine the involvement of the $s t_{2}$ receptor directly, binding studies with subsequent autoradiography were conducted using $\left[{ }^{125} \mathrm{I}\right] \mathrm{Tyr}^{3}$ octreotide. Statistically significant decreases in binding were observed in the chronic citalopram group in two areas; FrCxd $(-39.8 \pm 6.6 \%$, $p<0.05)$ and AId $(-43.3 \pm 8.0 \%, \quad p<0.05)$ layers (Figure 3c; Table 1). One-way ANOVA followed by the post-test for linear trend depicted a statistically significant trend of binding to decrease in FrCxs $(p<0.05)$, FrCxd $(p<0.05)$, and AIs $(p<0.05)$ (Figure 3c; Table 1) as exposure to citalopram was increasing. $\left[{ }^{125} \mathrm{I}\right] \mathrm{Tyr}^{3}$ octreotide binding did not change after DMI acute or chronic treatment (Table 2).

Two-way ANOVA for randomized-block data followed by the Bonferroni post-test located the source of variation (radioligand and/or treatment) between the binding of radioligands $v s$ antidepressant treatment. The decrease of $\left[{ }^{125}\right.$ I]LTT SRIF-28 binding observed in FrCxs, FrCxd, and AId layers after chronic citalopram treatment can be attributed to decreased $s t_{2}$ receptor binding as indicated by $\left[{ }^{125} \mathrm{I}\right] \mathrm{Tyr}^{3}$ octreotide binding (Table 1). The increase of $\left[{ }^{125}\right.$ I]LTT SRIF-28 binding observed in the CA1 hippocampal field after acute citalopram as well as acute and chronic DMI treatment can be attributed to decreased $s t_{1 / 4}$ 
Table I Effect of Acute and Chronic Citalopram Treatment on SRIF Receptor Binding in Rat Brain

[25] $]$ LTT SRIF-28

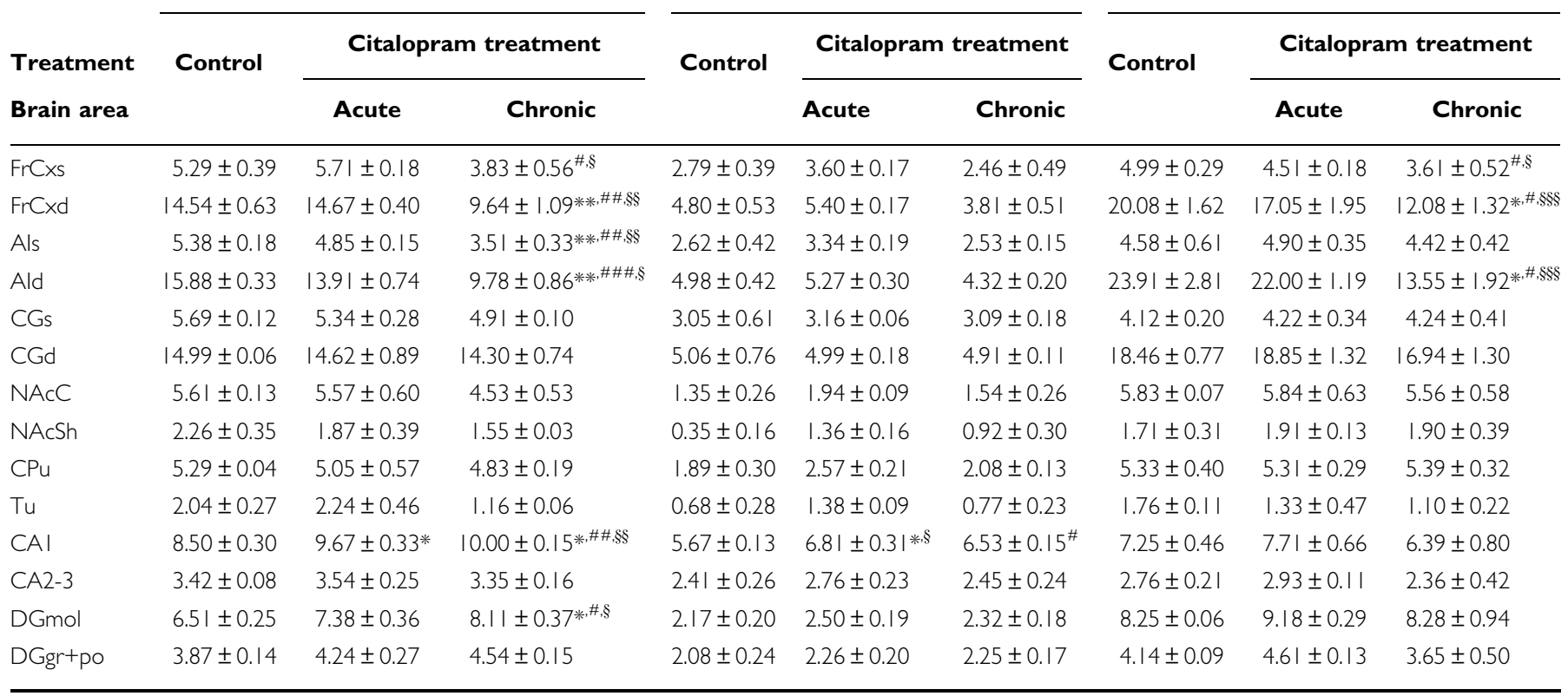

All values shown represent specific radioligand binding in $\mathrm{nCi} / \mathrm{mg}$ of protein.

Data are means \pm SEM measured in three rats per experimental group and $\mathrm{I}-5$ sections for each brain area per animal.

The asterisk '*' corresponds to statistically significant changes in radioligand binding between control and acutely or chronically citalopram-treated animals for each radioligand and brain area using one-way ANOVA followed by the Dunnett's multiple comparison post-test.

The sharp "\#' indicates statistically significant linear trend of radioligand binding to increase (or decrease) as exposure to citalopram increases for each radioligand and brain area, using one-way ANOVA followed by the post-test for linear trend.

The paragraph symbol \&' represents statistically significant changes of the radioligand binding attributable to acute or chronic citalopram treatment within each brain area, using two-way ANOVA for randomized-block data followed by the Bonferroni post-test.

The number of symbols repetition represents: I, $p<0.05 ; 2, p<0.01 ; 3, p<0.001$.

For the abbreviations of brain areas see Figure 2.

receptor binding as indicated by [ ${ }^{125}$ I]LTT SRIF- $28+3 \mathrm{nM}$ MK678 binding (Figure 4; Tables 1 and 2).

The data presented as controls in Tables 1 and 2 and Figures 3 and 4 were obtained from animals that received saline once daily $(2 \mathrm{ml} / \mathrm{kg})$ for 21 days, according to the injection protocol of the citalopram group. Subsequent studies were performed to examine whether the injection schedule influenced the binding characteristics of the radioligands employed in the different brain regions. As shown in Table 3, no differences were observed in the binding characteristics of the radioligands in the brain regions of animals injected once or twice daily $(2 \mathrm{ml} / \mathrm{kg})$ for 21 days. Owing to the fact that the manufacturer stopped producing $\left[{ }^{125} \mathrm{I}\right]$-microscales, the data presented in Table 3 are in OD units, in contrast to the data shown in Tables 1 and 2 presented in $\mathrm{nCi} / \mathrm{mg}$.

Finally, in comparing the influence of citalopram on SRIF tissue levels and radioligand binding, it is worth noticing that both SRIFergic system components (peptide and SRIF receptor binding) have the tendency to change in the frontal cortex and hippocampus (see one-way ANOVA followed by linear trend post-test in Figure 1, 3 and Table 1).

\section{DISCUSSION}

The presence of SRIF in brain nuclei with known involvement in affective behaviors may have an impact on normal or pathological brain function, such as depression. The question as to the putative involvement of SRIF in (1) depression or (2) in the actions of antidepressants is not new. However, no answers have been adequately provided to date. Owing to lack of adequate animal models for depression, chronic antidepressant treatment has been used as a paradigm to study this conjecture.

In this study, we demonstrated that acute and chronic administration of the SSRI citalopram influences SRIF levels in PFCx, Cpu, NAc, and hippocampus whereas the tricyclic antidepressant DMI had no effect. The present data also support a down- and upregulation of $s s t_{2}$ and $s t_{1 / 4}$ SRIF receptors in cortical and hippocampal areas, respectively, and an upregulation of the sst $_{1 / 4}$ receptors in the hippocampus after acute and chronic DMI treatment.

Earlier studies from our laboratory showed that chronic administration of DMI resulted in an increase (marginal) in $\left.{ }^{[25} \mathrm{I}\right] \mathrm{Tyr}^{11}$-SRIF binding (Gheorvassaki et al, 1992), and an exaggerated SRIF-induced increase in dopamine levels exclusively in the NAc (Pallis et al, 2001). Data from the literature have shown that repeated administration of two SSRIs, clomipramine and zimelidine, resulted in a widespread reduction in SRIF levels in brain tissues (the NAc was not mentioned), whereas imipramine had no effect (Kakigi et al, 1992). In addition, long-term treatment with a serotonin synthesis inhibitor and the serotonin-specific neurotoxin 5,7-dihydroxytryptamine (5,7-DHT) resulted in an elevation of SRIF levels in brain tissues including the 
Table 2 Effect of Acute and Chronic DMI Treatment on SRIF Receptor Binding in Rat Brain

\begin{tabular}{|c|c|c|c|c|c|c|c|c|c|}
\hline \multirow{3}{*}{$\begin{array}{l}\text { Treatment } \\
\text { Brain area }\end{array}$} & \multicolumn{3}{|c|}{$\left[{ }^{125} I\right]$ LTT SRIF-28 } & \multicolumn{3}{|c|}{$\left[{ }^{125}\right.$ I]LTT SRIF-28+3 nM MK678 } & \multicolumn{3}{|c|}{$\left[{ }^{125} I\right] \mathrm{Tyr}^{3}$ octreotide } \\
\hline & \multirow{2}{*}{ Control } & \multicolumn{2}{|c|}{ DMI treatment } & \multirow{2}{*}{ Control } & \multicolumn{2}{|c|}{ DMI treatment } & \multirow{2}{*}{ Control } & \multicolumn{2}{|c|}{ DMI treatment } \\
\hline & & Acute & Chronic & & Acute & Chronic & & Acute & Chronic \\
\hline $\mathrm{FrCxs}$ & $5.29 \pm 0.39$ & $5.98 \pm 0.87$ & $4.41 \pm 0.02$ & $2.79 \pm 0.39$ & $3.85 \pm 0.10 *$ & $2.51 \pm 0.13$ & $4.99 \pm 0.29$ & $5.83 \pm 0.37$ & $5.18 \pm 0.70$ \\
\hline Ald & $15.88 \pm 0.33$ & $15.52 \pm 1.62$ & $12.30 \pm 0.13^{\#}$ & $4.98 \pm 0.42$ & $5.93 \pm 0.47$ & $4.53 \pm 0.17$ & $23.91 \pm 2.81$ & $23.88 \pm 1.38$ & $24.47 \pm 1.52$ \\
\hline CGs & $5.69 \pm 0.12$ & $5.12 \pm 0.47$ & $5.66 \pm 0.54$ & $3.05 \pm 0.61$ & $3.45 \pm 0.42$ & $3.78 \pm 0.41$ & $4.12 \pm 0.20$ & $5.21 \pm 0.36$ & $4.57 \pm 0.25$ \\
\hline CGd & $14.99 \pm 0.06$ & $16.36 \pm 1.74$ & $14.08 \pm 0.78$ & $5.06 \pm 0.76$ & $6.05 \pm 0.43$ & $5.83 \pm 0.42$ & $18.46 \pm 0.77$ & $22.89 \pm 1.56$ & $20.01 \pm 0.67$ \\
\hline $\mathrm{NAcC}$ & $5.61 \pm 0.13$ & $4.79 \pm 2.23$ & $4.78 \pm 0.44$ & $1.35 \pm 0.26$ & $1.60 \pm 0.44$ & $1.71 \pm 0.39$ & $5.83 \pm 0.07$ & $6.97 \pm 0.33$ & $6.38 \pm 0.40$ \\
\hline NAcSh & $2.26 \pm 0.35$ & $2.17 \pm 0.56$ & $2.36 \pm 0.13$ & $0.35 \pm 0.16$ & $1.05 \pm 0.28$ & $1.04 \pm 0.29$ & $1.71 \pm 0.31$ & $3.00 \pm 0.41$ & $1.92 \pm 0.27$ \\
\hline CA2-3 & $3.42 \pm 0.08$ & $3.28 \pm 0.24$ & $3.22 \pm 0.46$ & $2.41 \pm 0.26$ & $3.06 \pm 0.13$ & $2.40 \pm 0.07$ & $2.76 \pm 0.21$ & $3.03 \pm 0.36$ & $2.58 \pm 0.16$ \\
\hline DGmol & $6.51 \pm 0.25$ & $7.97 \pm 0.74$ & $6.67 \pm 0.58$ & $2.17 \pm 0.20$ & $2.54 \pm 0.08$ & $2.22 \pm 0.21$ & $8.25 \pm 0.06$ & $9.06 \pm 1.27$ & $8.66 \pm 0.36$ \\
\hline DGgr+po & $3.87 \pm 0.14$ & $4.32 \pm 0.51$ & $4.21 \pm 0.35$ & $2.08 \pm 0.24$ & $2.45 \pm 0.03$ & $2.12 \pm 0.30$ & $4.14 \pm 0.09$ & $4.66 \pm 0.68$ & $3.86 \pm 0.11$ \\
\hline
\end{tabular}

All values shown represent specific radioligand binding in $\mathrm{nCi} / \mathrm{mg}$ of protein.

Data are means \pm SEM measured in three rats per experimental group and $I-5$ sections for each brain area per animal.

The asterisk '**' corresponds to statistically significant changes in radioligand binding between control and acutely or chronically DMI-treated animals for each radioligand and brain area using one-way ANOVA followed by the Dunnett's multiple comparison post-test.

The sharp '\#' indicates statistically significant linear trend of radioligand binding to increase (or decrease) as exposure to DMI increases for each radioligand and brain area, using one-way ANOVA followed by the post-test for linear trend.

The paragraph symbol «' represents statistically significant changes of the radioligand binding attributable to acute or chronic citalopram treatment within each brain area, using two-way ANOVA for randomized-block data followed by the Bonferroni post-test.

The number of symbol repetition represents: I, $p<0.05 ; 2, p<0.0$ I; $3, p<0.00$ I.

For the abbreviations of brain areas see Figure 2.

CA1

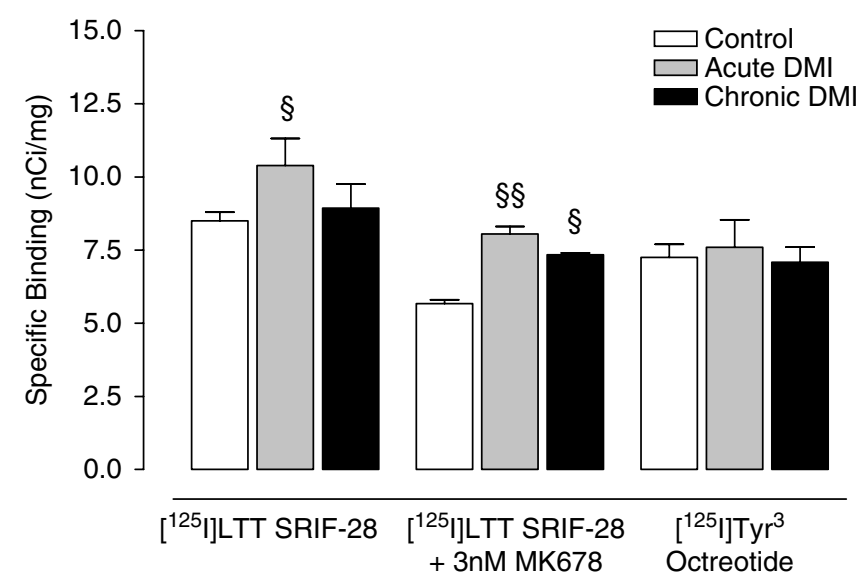

Figure 4 Effect of acute and chronic desmethylimipramine (DMI) administration on ${ }^{125}$ I]LTT SRIF-28, $\left[{ }^{125} \mid\right] \mathrm{LTT}$ SRIF-28 + MK678, and $\left[{ }^{125} \mathrm{I}\right] \mathrm{Tyr}^{3}$ octreotide binding in CAI hippocampal field. Data are mean$s \pm S E M$ measured in three rats per experimental group and one to five sections for each brain area per animal. ${ }^{\S} p<0.05,{ }^{\S \S} p<0.0$ I: statistically significantly different from control groups using a two-way analysis of variance (ANOVA) for randomized-block data followed by the Bonferroni post-test was performed to locate the source of variation (radioligand and/ or treatment). hippocampus, striatum, and cerebral cortex, suggesting that SRIF is under the negative control of serotonin (Kakigi and Maeda, 1992). However, in another study in the hippocampus 5,7-DHT had no effect on SRIF-LI (Munoz-Acedo et al, 1992).

In a study by Prosperini et al (1997) a reduction of SRIF levels in the NAc and striatum was observed after $4 \mathrm{~h}$ of administration of a single dose of citalopram $(10 \mathrm{mg} / \mathrm{kg}$, i.p., same dose as in the present study. Also, $1 \mathrm{~h}$ after a single injection of citalopram $(10 \mathrm{mg} / \mathrm{kg}$, i.p. $)$ a significant $\mathrm{K}^{+}$evoked increase of SRIF release was observed in striatal slices. Chronic citalopram administration resulted in a decrease of SRIF levels and its mRNA in the striatum. The investigators suggested that acute citalopram treatment reduces SRIF levels by increasing the release of the peptide, whereas chronic citalopram treatment reduces the biosynthesis of the peptide (Prosperini et al, 1997). The data on the acute and chronic treatment with citalopram are in disagreement with the study by Kakigi et al (1992), who showed no changes in SRIF levels after the acute administration of another SSRI, chlorimipramine, and reduction in SRIF levels also in the hippocampus and the NAc.

In a more recent study, Pallis et al (2006) provided in vivo evidence in the awake animal that the antidepressants, DMI and citalopram, influence SRIF levels (release) in a positive 
Table 3 Effect of the Injection Protocol on [ $\left.\left.{ }^{125}\right]\right]$ LTT SRIF-28, [ $\left.{ }^{125}\right]$ LTT SRIF-28+MK678, and [ $\left.{ }^{125} \mid\right] T y r^{3}$ octreotide Binding in Rat Brain

\begin{tabular}{|c|c|c|c|c|c|c|}
\hline \multirow[b]{2}{*}{ Treatment } & \multicolumn{2}{|c|}{$\left[{ }^{125}\right.$ I]LTT SRIF-28 } & \multicolumn{2}{|c|}{$\left[{ }^{125}\right.$ I]LTT SRIF-28+3 nM MK678 } & \multicolumn{2}{|c|}{$\left[{ }^{125} 1\right] \mathrm{Tyr}^{3}$ octreotide } \\
\hline & $\begin{array}{c}2 \mathrm{ml} / \mathrm{kg} \text {, i.p. saline } \\
\text { Once daily }\end{array}$ & $\begin{array}{c}2 \mathrm{ml} / \mathrm{kg} \text {, i.p. saline } \\
\text { Twice daily }\end{array}$ & $\begin{array}{c}2 \mathrm{ml} / \mathrm{kg} \text {, i.p. saline } \\
\text { Once daily }\end{array}$ & $\begin{array}{c}2 \mathrm{ml} / \mathrm{kg} \text {, i.p. saline } \\
\text { Twice daily }\end{array}$ & $\begin{array}{c}2 \mathrm{ml} / \mathrm{kg} \text {, i.p. saline } \\
\text { Once daily }\end{array}$ & $\begin{array}{c}2 \mathrm{ml} / \mathrm{kg} \text {, i.p. saline } \\
\text { Twice daily }\end{array}$ \\
\hline $\mathrm{FrCxs}$ & $0.103 \pm 0.003$ & $0.109 \pm 0.005$ & $0.063 \pm 0.004$ & $0.063 \pm 0.000$ & $0.104 \pm 0.005$ & $0.105 \pm 0.002$ \\
\hline $\mathrm{FrCxd}$ & $0.232 \pm 0.008$ & $0.240 \pm 0.006$ & $0.106 \pm 0.007$ & $0.101 \pm 0.002$ & $0.340 \pm 0.017$ & $0.334 \pm 0.008$ \\
\hline CGs & $0.090 \pm 0.003$ & $0.094 \pm 0.006$ & $0.056 \pm 0.002$ & $0.056 \pm 0.002$ & $0.100 \pm 0.002$ & $0.102 \pm 0.002$ \\
\hline CGd & $0.233 \pm 0.013$ & $0.221 \pm 0.011$ & $0.091 \pm 0.002$ & $0.095 \pm 0.006$ & $0.354 \pm 0.010$ & $0.35 I \pm 0.002$ \\
\hline $\mathrm{NAcC}$ & $0.046 \pm 0.001$ & $0.055 \pm 0.004$ & $0.015 \pm 0.002$ & $0.015 \pm 0.002$ & $0.090 \pm 0.006$ & $0.097 \pm 0.005$ \\
\hline NAcSh & $0.022 \pm 0.003$ & $0.023 \pm 0.000$ & $0.011 \pm 0.003$ & $0.008 \pm 0.001$ & $0.035 \pm 0.003$ & $0.045 \pm 0.002$ \\
\hline $\mathrm{CPu}$ & $0.049 \pm 0.004$ & $0.055 \pm 0.005$ & $0.022 \pm 0.001$ & $0.023 \pm 0.003$ & $0.074 \pm 0.003$ & $0.087 \pm 0.005$ \\
\hline DGmol & $0.111 \pm 0.004$ & $0.118 \pm 0.010$ & $0.028 \pm 0.003$ & $0.030 \pm 0.003$ & $0.169 \pm 0.006$ & $0.174 \pm 0.010$ \\
\hline DGgr+po & $0.064 \pm 0.002$ & $0.069 \pm 0.007$ & $0.025 \pm 0.005$ & $0.023 \pm 0.003$ & $0.074 \pm 0.003$ & $0.077 \pm 0.008$ \\
\hline
\end{tabular}

Control animals received saline ( $2 \mathrm{ml} / \mathrm{kg}$, i.p.) for $2 \mathrm{l}$ days, once or twice daily according to the citalopram and DMl injection protocol, respectively.

All values shown represent specific radioligand binding calculated as OD assessed in total binding minus OD assessed in the presence of I $\mu$ M SRIF-28 (nonspecific binding).

Data are means \pm SEM measured in four rats per group and I-3 sections for each brain area per animal.

For each one of the radioligands a two-way ANOVA, followed by the Bonferroni post-test, was performed to locate the source of variation (brain area and/or injection protocol). For all three radioligands, the source of variation were the different brain areas studied $(p<0.00 \mathrm{I})$ while the injection protocol used had no effect on the results $(P>0.05)$

For the abbreviations of brain areas see Figure 2.

manner in the NAc when administered chronically (i.p.). This increase in SRIF levels may have ramifications on the pharmacological actions of the antidepressants, as the levels of SRIF were reported to be attenuated in the CSF of depressed patients (Gerner and Yamada, 1982; Bissette et al, 1986). Although there is no direct evidence that SRIF or its agonists are efficacious as antidepressants (there are no clinically used brain penetrating SRIF receptor agonists), SRIF may act indirectly to influence other neurotransmitter systems known to be instrumental in the pathophysiology and therapeutics of depression, such as the norepinephrine (NE), dopamine, or serotonin systems. In the study by Pallis et al (2006), the data showed a statistically significant difference in SRIF levels in the two antidepressant treatment groups suggesting a larger serotonin influence on the SRIF system.

To pursue the former finding, the present study focused on whether acute and chronic citalopram and DMI treatments influence SRIF tissue levels and SRIF receptors in different brain regions. Control tissue levels in the four brain areas studied varied in the measurements made during the citalopram and the DMI studies. Comparable variability has been reported in the literature (Kakigi et al, 1992; Kakigi and Maeda, 1992; Bissette, 2001). Although the experimental conditions of the present studies were similar, the experiments for each antidepressant were performed at different times. We have repeated the control experiments for each antidepressant under the exact same conditions. Differences were still observed in the PFCx and the $\mathrm{CPu}$, but not the NAc and the hippocampus (data not shown). These findings support that one cannot generalize that the differences in SRIF levels are due to the injection scheme or other parameters. Therefore, for every experiment, parallel controls need to be performed, as the baseline may shift.

In the NAc and the PFCx, the SRIF tissue levels were found to be increased in a statistically significant manner in rats treated acutely and chronically with citalopram. In the $\mathrm{CPu}$ and the hippocampus an increase was observed only in the acute and chronically treated groups, respectively. These areas of study were chosen for their known involvement in affective disorders, actions of antidepressant treatment and previous data from our group. The present data are not in agreement with the results by Kakigi et al (1992) where chronic SSRI (clomipramine) treatment resulted in a reduction in SRIF levels in cortex, hippocampus, and the striatum, whereas zimelidine reduced SRIF levels in the hypothalamus and the thalamus. Also, in the Kakigi et al (1992) study, no effect was observed after acute administration of the antidepressants. In contrast, a reduction of SRIF levels was observed in the NAc and the striatum $4 \mathrm{~h}$ after the administration of a single dose of citalopram (same dose as in the present study), whereas chronic citalopram administration resulted in a decrease of SRIF and its mRNA only in the striatum (Prosperini et al, 1997).

Although there are discrepancies between the cited studies, as to the brain regions where SRIF levels are influenced by acute or chronic SSRI treatment, they do 
agree on a negative regulation of the levels or synthesis of SRIF. The present study is most similar to the Prosperini study, in which both employed the same SSRI, citalopram, but differs in the dosage protocol (Prosperini study: $10 \mathrm{mg} /$ $\mathrm{kg}$ twice daily for 14 days, present study: $20 \mathrm{mg} / \mathrm{kg}$ once daily for 21 days). Another study, examining the effects of the SSRI sertraline $(10 \mathrm{mg} / \mathrm{kg}, 5$ weeks $)$ on regional neuropeptide concentrations in sham and olfactory bulbectomized rats, noted either no changes in SRIF levels between the sham-sertraline and the sham-vehicle groups in most regions studied or a decrease (anterior caudate and piriform cortex) or an increase (Tu) in SRIF levels (Bissette, 2001). Earlier studies have shown serotonin to decrease SRIF release in rat hypothalamus both in vivo and in vitro (Chihara et al, 1979; Richardson et al, 1981).

SSRIs increase serotonin levels and influence the plethora of serotonin receptors in different brain regions. This influence may result in the desensitization of receptors such as $5 \mathrm{HT}_{1 \mathrm{~A}}$ or $5 \mathrm{HT}_{1 \mathrm{~B} / 1 \mathrm{D}}$ and others and lead to the decrease of their densities (Charney et al, 1981; Stahl, 1998). Therefore, the effect of serotonin receptor activation on SRIF levels depends on the type and localization (autoreceptors, preand post-synaptic) of serotonin receptors present in the different brain regions and how these receptors are affected by the acute or chronic treatment with antidepressants (for review see Stahl, 1998).

The present findings in conjunction with the cited literature reveal that there are major discrepancies regarding the role of SSRIs on SRIF levels in brain. One can attempt to justify these discrepancies by examining the different parameters that could influence the measurements of the SRIF levels in the different cited studies, namely the antibodies, tissue levels vs CSF levels of in vivo studies, etc. Two studies in our own laboratory using the same antibody for the quantification of SRIF levels suggest that such comparisons may not afford the answers needed to solve the divergence of the cited data. Chronic citalopram treatment increased the release of SRIF as measured in CSF samples in the NAc (microdialysis study), whereas in the same region and using the same treatment SRIF tissue levels were also increased, suggestive of a decrease in SRIF release (Pallis et al, $2006 v s$ present study).

No changes were observed in SRIF tissue levels in the DMI-treated animals. These data are in partial agreement with earlier findings that showed acute DMI treatment not to affect SRIF-LI levels in the hippocampus (Lopez-Sanudo and Arilla, 1992). Also, repeated administration of the tricyclic imipramine had no effect on SRIF levels in the striatum, the hippocampus, the cerebral cortex, and other areas studied (Kakigi et al, 1992). In the in vivo microdialysis study by Pallis et al (2006), an increase in SRIF release was observed in the NAc of both DMI and citalopram chronically treated animals, even though the changes were approximately half in the DMI group. The lack of effect of the DMI treatment in SRIF tissue levels may suggest that under these conditions SRIF is found mostly in the extracellular space.

SRIF receptors have been localized in the abovementioned brain regions (Fehlmann et al, 2000; Schulz et al, 2000). With the cloning of the SRIF receptors (Hoyer et al, 1995), tools have become available to study the presence of each receptor subtype. mRNA studies depicted the presence of the sst $_{1}$ receptor in the outer and intermediate layers of the cerebral cortex. The hippocampal formation contains $s t_{1 / 4}$ subtypes, with the CA1 expressing predominantly the sst $_{4}$ subtype (Thoss et al, 1995; Videau et al, 2003). sst $_{2 \mathrm{~A}}$ receptor immunoreactivity was most prominent in the Tu, layers II-III of the cerebral cortex, NAc, pyramidal cells of CA1-2 subfields of the hippocampus, central and cortical amygdaloid nuclei (Dournaud et al, 1998; Schindler et al, 1998; Schulz et al, 2000).

In the present study, radioligand binding with subsequent autoradiography was employed to acquire a greater sensitivity of detection and specific anatomical information. We examined whether specific SRIF receptor subtypes may be involved in the different regions, something that would have been masked when measuring $\left[{ }^{125} \mathrm{I}\right] \mathrm{Tyr}^{11}$ SRIF binding in membrane preparations. This was indeed the case, as differences in binding were observed in the autoradiography studies in different layers of cortex and the hippocampus as a result of the antidepressant treatment.

$\left[{ }^{125}\right.$ I]LTT SRIF-28 binding, which labels all SRIF receptors, depicted a statistically significant decrease in binding in the deep layers of the frontal association cortex and secondary motor cortex (FrCxd), the superficial (AIs) and deep (AId) layers of the AI cortex. This decrease in binding is due to the sst $_{2}$ subtype, as substantiated by the $\left[{ }^{125} \mathrm{I}\right] \mathrm{Tyr}^{3}$ octreotide binding studies.

The evidence presented suggests that citalopram administration has a wide and differential influence on SRIF receptors in different brain areas. The analysis of the autoradiography data strongly supports a downregulation of the receptors $\left(s s t_{2}\right)$ found in the cortical areas and an upregulation of the $s t_{1 / 4}$ receptors in the hippocampus after chronic citalopram administration. SRIF tissue levels were increased in the PFCx of acute and chronic citalopramtreated rats, but receptor changes were observed only in the chronically treated group. Receptor changes were not observed in other areas, such as the NAc where SRIF levels were also elevated after acute or chronic administration or in the $\mathrm{CPu}$ after acute citalopram administration. Therefore, there is a lack of concordance between SRIF levels and sst regulation in these brain areas. One can conjecture that synaptic processes such as SRIF release or metabolism may differentially influence receptor regulation, but there are no data to substantiate this hypothesis.

It would be a simplification to suggest that the decrease in sst $_{2}$ binding in the different cortical areas shown is due to the changes in SRIF levels observed in the membrane preparation of the PFCx. Subsequent SRIF measurements in each cortical layer examined in the autoradiography studies were not attempted fearing low protein concentrations and inability to obtain results. In cortex and hippocampus, the $\mathrm{sst}_{2 \mathrm{~A}}$ receptor has been shown to internalize in response to SRIF release (Dournaud et al, 1998) and to be involved in the neuronal endocytosis of SRIF (Stroh et al, 2000). The present data clearly suggest such an internalization of the sst $_{2}$ receptors in the cortical layers as a result of the increases in SRIF levels.

In the hippocampus (CA1 and dentate gyrus (molecular)), the $\left[{ }^{125}\right.$ I]LTT SRIF-28 binding was increased in the chronic citalopram-treated animals. SRIF levels were only increased in the hippocampus of the chronic citalopram group. These changes were not due to $\mathrm{sst}_{2}$ involvement, as 
$\left[{ }^{125} \mathrm{I}\right] \mathrm{Tyr}^{3}$ octreotide binding was not affected. In contrast, the changes in the CA1 region were due to the $s s t_{1 / 4}$ receptors. The $s t_{1}$ and sst $_{4}$ subtypes are found in the hippocampus but unlike the sst $_{2}$ subtype were shown to have poor internalization yields (Nouel et al, 1997; Kreienkamp et al, 1998; Stroh et al, 2000). In a recent publication new evidence is provided showing that $s t_{1}$ mediates agonist-induced endocytosis, recycling and reendocytosis of its cognate ligand (Roosterman et al, 2007). The present findings clearly support an upregulation of the $\mathrm{sst}_{1 / 4}$ receptors in the hippocampus after chronic administration of citalopram.

DMI also influenced the SRIF systems yet in a more restricted manner. An increase in $\left[{ }^{125} \mathrm{I}\right] \mathrm{LTT}$ SRIF-28 binding in the CA1 region in the acute treated, and an upregulation of $s t_{1 / 4}$ ([ ${ }^{125}$ I]LTT SRIF-28 + MK678 binding) in the CA1 region of both acute and chronic DMI groups were observed. A trend for a decrease in [ ${ }^{125}$ I]LTT SRIF-28 binding in the AIs and AId of the cortex as exposure to DMI increases was observed. However, a similar trend was not observed in the $\left[{ }^{125} \mathrm{I}\right] \mathrm{LTT}$ SRIF-28 + MK678 or $\left[{ }^{125} \mathrm{I}\right] \mathrm{Tyr}^{3}$ octreotide binding. This finding cannot be attributed to the sst $_{1 / 4}$ or sst $_{2}$ subtypes and thus is not easily explained. It may be due to either $s t_{1}$ or sst $_{4}$ alone, something that we cannot examine due to lack of specific radioligands. In the NAc, no change was observed in the density of any receptor, suggesting that the marginal increase in $\left[{ }^{125} \mathrm{I}\right] \mathrm{Tyr}^{11}$ SRIF binding in membrane preparations as presented by our earlier work (Gheorvassaki et al, 1992) was indeed not significant.

The mechanisms involved in the regulation of the receptors under acute or chronic antidepressant treatment cannot be explained by the direct comparisons of receptor concentrations and SRIF levels in different brain regions. What can be said with certainty is that the present findings suggest that acute and chronic citalopram and DMI treatments regulate SRIF receptors, implicate the already known targets of the pharmacological actions of SSRIs and tricyclics, namely areas of the cortex, and hippocampal formation, and propose a role for SRIF receptors in their pharmacological actions.

Citalopram, as a member of the SSRI family, influences serotonin neurotransmission not only by blocking its reuptake but by also influencing the function of specific serotonin receptors (Barnes and Sharp, 1999). Acute citalopram treatment increased both agonist and antagonist binding to $5-\mathrm{HT}_{2 \mathrm{C}}$ receptors, but only chronic citalopram treatment increased PI hydrolysis (Palvimaki et al, 2005), suggesting a role of the $5-\mathrm{HT}_{2 \mathrm{C}}$ receptor in the antidepressant action of this drug. To our knowledge, citalopram has not been reported to have any affinity or direct influence on SRIF receptors. Other serotonin receptors, such as the $5-\mathrm{HT}_{2 \mathrm{~A}}$, are influenced and downregulated by chronic antidepressant treatment. A role for the $5-\mathrm{HT}_{1 \mathrm{~A}}$ receptor is also discussed, as drugs like buspirone and gepirone have antidepressant effects and augmentation strategies are using combinations of SSRIs and $5-\mathrm{HT}_{1 \mathrm{~A}}$ antagonists, such as pindolol (Artigas et al, 2006).

A large body of experimental findings attempts to resolve the yet unanswered questions regarding SSRIs, the cellular and molecular mechanisms involved in their onset of action, and the neuronal circuits in brain involved in depression and its therapeutics. Answers to some of these questions will be instrumental in resolving issues such as why increases in SRIF levels downregulate SRIF receptors in cortical areas, upregulate SRIF receptors in the hippocampus, and have no effect in areas such as the $\mathrm{CPu}$ and the NAc.

In the hippocampus, an area associated with cognitive abnormalities, it has been suggested that SRIF receptors may be localized presynaptically on the serotoninergic nerve terminals (Munoz-Acedo et al, 1992). More recently, SRIF has been found to be colocalized with $5-\mathrm{HT}_{2 \mathrm{~A}}$ receptors in the CA1 and dentate gyrus of the hippocampus (Luttgen et al, 2004).

DMI, is a member of the tricyclic family and influences NE neurotransmission by blocking its reuptake. The NE transporter has been found in different regions of the brain where it has been reported to be involved not only in NE clearance, but also in that of dopamine (Carboni et al, 2001) and serotonin (Daws et al, 1998). There are reports suggesting NE-SRIF interactions. SRIF receptors are present in the locus coeruleus either in the vicinity of NEcontaining cell bodies or on NE-containing cells, suggesting that SRIF can influence locus coeruleus physiology (Epelbaum et al, 1990). Also, in the hippocampus SRIF receptors may be localized presynaptically on noradrenergic nerve terminals (Lopez-Sanudo and Arilla, 1992). These studies, however, do not provide explanations on how increased levels of $\mathrm{NE}$, and possibly serotonin, in the hippocampus may influence the release of SRIF and the subsequent regulation of its receptors.

Although different peptidergic neurotransmitter systems (substance P, neuropeptide Y, galanin, and CRH) have been proposed as new antidepressant drug discovery targets (Berton and Nestler, 2006), less attention has been given to SRIF. The novelty of the present work is that it provides new information on the changes bestowed on specific SRIF receptor subtypes in different brain regions differentially affected by two antidepressants, the SSRI citalopram and the tricyclic DMI. Although direct conclusions as to the role of SRIF in depression cannot be drawn, the results provide new findings and support further studies using existing animal models of depression to assess the putative antidepressant actions of SRIF.

\section{ACKNOWLEDGEMENTS}

This work was supported by the Ministry of Education (EPEAEK Neuroscience, University of Crete) to KT and an EC contract (QLG3-CT-1999-00908) to KT and DH.

\section{DISCLOSURE/CONFLICT OF INTEREST}

There is no conflict of interest for any of the authors.

\section{REFERENCES}

Artigas F, Adell A, Celada P (2006). Pindolol augmentation of antidepressant response. Current Drug Targets 7: 139-147.

Barnes NM, Sharp T (1999). A review of central 5-HT receptors and their function. Neuropharmacology 38: 1083-1152. 
Berton O, Nestler EJ (2006). New approaches to antidepressant drug discovery: beyond monoamines. Nat Rev Neurosci 7: $137-151$.

Bissette G (2001). Effects on regional neuropeptide concentrations in olfactory bulbectomized rats. Pharmacol Biochem Behav 69: 269-281.

Bissette G, Klime V, Pan J, Stockmeier C, Ordway G (2003). Elevated concentrations of CRF in the locus coeruleus of depressed subjects. Neuropsychopharmacology 28: 1328-1335.

Bissette G, Widerlov E, Walleus H, Karlsson I, Eklund K, Forsman A et al (1986). Alterations in cerebrospinal fluid concentrations of somatostatin like immunoreactivity in neuropsychiatric disorders. Arch Gen Psych 43: 1148-1151.

Bradford MM (1976). A rapid and sensitive method for the quantification of microgram quantities of protein utilizing the principle of protein-dye binding. Analyt Biochem 72: 248-254.

Brownstein MJ, Arimura A, Sato H, Schally AV, Kizer JS (1975). The regional distribution of somatostatin in the rat brain. Endocrinology 96: 1456-1461.

Carboni E, Spielewoy C, Vacca C, Nosten-Bertrand M, Giros B, Di Chiara G (2001). Cocaine and amphetamine increase extracellular dopamine in the nucleus accumbens of mice lacking the dopamine transporter gene. J Neurosci 21: RC141(1-4).

Charlton B, Leake A, Wright C, Fairbairan AF, McKeith IG, Candy JM et al (1988). Somatostatin content and receptors in cerebral cortex of depressed and control subjects. J Neurol Neurosurg Psychiatry 51: 719-721.

Charney DS, Menkes DB, Heninger GR (1981). Receptor sensitivity and the mechanisms of action of antidepressant treatment: implications for the etiology and therapy of depression. Arch Gen Psychiatry 38: 1160-1180.

Chihara K, Arimura A, Schally AV (1979). Effects of intraventricular injection of dopamine, norepinephrine, acetylcholine, and 5-hydroxytryptamine on immunoreactive somatostatin release into rat hypophyseal portal blood. Endocrinology 104: 1656-1661.

Daws C, Toney GM, Gerhardt GA, Frazer A (1998). In vivo chronoamperometric measures of extracellular serotonin clearance in rat dorsal hippocampus: contribution of serotonin and norepinephrine transporters. J Pharmacol Exp Ther 286: 967-976.

Dournaud P, Boudin H, Schonbrunn A, Tannenbaum GS, Beaudet A (1998). Interrelationships between somatostatin sst2A receptors and somatostatin-containing axons in rat brain: evidence for regulation of cell surface receptors by endogenous somatostatin. J Neurosci 18: 1056-1071.

Epelbaum J, Blue-Pajot MT, Llorens-Cortes C, Kordon C, Mounier $\mathrm{F}$, Senut MC et al (1990). ${ }^{125} \mathrm{I}-\left[\mathrm{Tyr}^{\mathrm{o}}, \mathrm{D}-\mathrm{Trp}^{8}\right]$ somatostatin-14 binding sites in the locus coeruleus of the rat are located on both ascending and descending projecting noradrenergic cells. Peptides 11: 21-27.

Fehlmann D, Langenegger D, Schuepbach E, Siehler S, Feuerbach D, Hoyer D (2000). Distribution and characterization of somatostatin receptor mRNA and binding sites in the brain and periphery. J Physiol Paris 94: 265-281.

Gerner RH, Yamada T (1982). Altered neuropeptide concentrations in cerebrospinal fluid of psychiatric patients. Brain Res 238: 298-302.

Gheorvassaki EG, Thermos K, Liapakis G, Spyraki C (1992). Effects of acute and chronic desipramine treatment on somatostatin receptors in brain. Psychopharmacology 108: 363-366.

Hathway GJ, Humphrey PP, Kendrick KM (1999). Evidence that somatostatin $\mathrm{sst}_{2}$ receptors mediate striatal dopamine release. $\mathrm{Br}$ J Pharmacol 128: 1346-1352.

Hoyer D, Bell GI, Berelowitz M, Epelbaum J, Feniuk W, Humprey $\mathrm{PP}$ et al (1995). Classification and nomenclature of somatostatin receptors. Trends Pharmacol Sci 16: 86-88.

Kakigi T, Maeda K (1992). Effect of serotonergic agents on regional concentration of somatostatin and neuropeptide Y-like immunoreactivities in rat brain. Brain Res 599: 42-50.
Kakigi T, Maeda K, Kaneda H, Chihara K (1992). Repeated administration of antidepressant drugs reduces regional somatostatin concentration in rat brain. J Affect Dis 25: 215-220.

Kramer MS, Cutler N, Feighner J, Shrivastava R, Carman J, Sramek JJ et al (1998). Distinct mechanism for antidepressant activity by blockade of central substance P receptors. Science 281: $1640-1645$.

Kreienkamp H-J, Roth A, Richter D (1998). Rat somatostatin receptor subtype 4 can be made sensitive to agonist-induced internalization by mutation of a single threonine (residue 331). DNA Coll Biol 17: 869-878.

Lopez-Sanudo S, Arilla E (1992). Desmethylimipramine pretreatment prevents 6-hydroxydopamine induced somatostatin receptor reduction in the rat hippocampus. Regul Pept 41: 227-236.

Luttgen M, OveOgren S, Meister B (2004). Chemical identity of 5HT2A receptor immunoreactive neurons of the rat septal complex and dorsal hippocampus. Brain Res 1010: 156-165.

Mikkelsen JD, Woldbye DPD (2006). Accumulated increase in neuropeptide $\mathrm{Y}$ and somatostatin gene expression of the rat in response to repeated electroconvulsive stimulation. J Psych Res 40: $153-159$.

Munoz-Acedo G, Lopez-Sanudo S, Arilla E (1992). Reduction of somatostatin receptors in rat hippocampus by treatment with 5,7-dihydroxytryptamine. Neurosci Lett 146: 60-64.

Nouel D, Gaudriault G, Goule M, Reisine T, Vincent J-P, Mazella J et al (1997). Differential internalization of somatostatin in COS-7 cells transfected with $s t_{1}$ and $s t_{2}$ receptor subtype: a confocal microscopic study using novel fluorescent somatostatin derivatives. Endocrinology 138: 296-306.

Palkovits M, Brownstein MJ (1988). Maps and Guides to Microdissection of the Rat Brain. Elsevier: New York.

Pallis E, Spyraki C, Thermos K (2006). Chronic antidepressant treatment modulates the release of somatostatin in the rat nucleus accumbens. Neurosci Lett 395: 76-81.

Pallis E, Thermos K, Spyraki C (2001). Chronic desipramine treatment selectively potentiates somatostatin-induced dopamine release in the nucleus accumbens. Eur J Neurosci 14: 763-767.

Palvimaki EP, Majasuo H, Syvalahti E, Hietala J (2005). Serotonin 5-HT2C receptor-mediated phosphoinositide hydrolysis in rat choroidplexus after fluoxetine and citalopram treatments. Pharmacol Res 51: 419-425.

Paxinos G, Watson C (1998). The Rat Brain in Stereotaxic Coordinates, 4th edn, Academic Press Inc: San Diego.

Pazzaglia PJ, George MS, Post RM, Rubinow DR, Davis CL (1995). Nimodipine increases somatostatin in affective ill patients. Neuropsychopharmacology 13: 75-83.

Prosperini E, Rizzi M, Fumagalli F, Tarizzo G, Samanin R, Bendotti C (1997). Acute and chronic treatments with citalopram lower somatostatin levels in rat brain striatum through different mechanisms. J Neurochem 69: 206-213.

Raynor K, Lucki I, Reisine T (1993). Somatostatin-1 receptors in the nucleus accumbens selectively mediate the stimulatory effect of somatostatin on locomotor activity. J Pharmacol Exp Ther 265: 67-73.

Richardson SB, Hollander CS, Prasad JA, Hirooka Y (1981). Somatostatin release from rat hypothalamus in vitro: effects of melatonin and serotonin. Endocrinology 109: 602-606.

Roosterman D, Kreuzer OJ, Brune N, Cottrell GS, Bunnett NW, Meyerhof W et al (2007). Agonist-induced endocytosis of rat somatostatin receptor 1. Endocrinology 148: 1050-1058.

Rubinow DR (1986). Cerebrospinal fluid somatostatin and psychiatric illness. Biol Psychiatry 21: 341-365.

Rubinow DR, Gold PW, Post R, Ballenger JC, Cowdry R, Bollinger J et al (1983). CSF somatostatin in affective illness. Arch Gen Psych 40: 409-412.

Schindler M, Kidd EJ, Carruthers AM, Jarvie EM, Sellers LA, Feniuk W et al (1998). Molecular cloning and functional 
characterization of a rat somatostatin sst2(B) receptor splice variant. Br J Pharmacol 25: 209-217.

Schulz S, Handel M, Schreff M, Schmidt H, Hollt V (2000). Localization of five somatostatin receptors in the rat central nervous system using subtype-specific antibodies. J Phys Paris 94: 259-264.

Siehler S, Seuwen K, Hoyer D (1999). Characterisation of human recombinant somatostatin receptors: 1 radioligand binding studies. Nauyn Schmied Arch Pharmacol 360: 488-499.

Skolnick P, Legutko B, Li X, Bymaster FP (2001). Current perspectives on the development of non-biogenic amine-based antidepressants. Pharmacol Res 43: 411-443.

Stahl SM (1998). Mechanism of action of serotonin selective reuptake inhibitors. Serotonin receptors and pathways mediate therapeutic effects and side effects. J Affect Dis 51: 215-235.

Stroh T, Jackson AC, Dal Farra C, Schonbrunn A, Vincent JP, Beaudet A (2000). Receptor-mediated internalization of somatostatin in rat cortical and hippocampal neurons. Synapse 38: 177-186.

Thermos K, Bagnoli P, Epelbaum J, Hoyer D (2006). The somatostatin sst $_{1}$ receptor: an autoreceptor for somatostatin in brain and retina? Pharmacol Ther 110: 455-464.

Thermos K, Radke J, Kastellakis A, Anagnostakis Y, Spyraki C (1996). Dopamine-somatostatin interactions in the rat striatum: an in vivo microdialysis study. Synapse 22: 209-216.
Thoss VS, Perez J, Duc D, Hoyer D (1995). Embryonic and postnatal mRNA distribution of five somatostatin receptor subtypes in the rat brain. Neuropharmacology 34: 1673-1688.

Vasilaki A, Papasava D, Hoyer D, Thermos K (2004). The somatostatin receptor $\left(\mathrm{sst}_{1}\right)$ modulates the release of somatostatin in the nucleus accumbens of the rat. Neuropharmacology 47: 612-618.

Videau C, Hochgeschwender U, Kreienkamp HJ, Brennan MB, Viollet C, Richter D et al (2003). Characterization of $\left[{ }^{125} \mathrm{I}\right]-$ $\mathrm{Tyr}^{0} \mathrm{D}$-Trp ${ }^{8}$-somatostatin binding in sst1- to sst4- and SRIFgene-invalidated mouse brain. Nauyn Schmied Arch Pharmacol 367: $562-571$.

Vincent SR, Johansson O (1983). Striatal neurons containing both somatostatin- and avian pancreatic polypeptide (APP)-like immunoreactivities and NADPH-diaphorase activity: a light and electron microscopic study. J Comp Neurol 217: 264-270.

Wong M, Licinio J (2004). From monoamines to genomic targets: a paradigm shift for drug discovery in depression. Nat Rev Drug Discov 3: 136-151.

Zobel AW, Nicke T, Kunze HE, Ackl N, Sonntag A, Ising M et al (2000). Effects of the high-affinity corticotropin-releasing hormone receptor 1 antagonist R121919 in major depression: the first 20 patients treated. J Psychiat Res 34: 171-181. 